\title{
The Effect of COVID-19 Pandemic on the Turkish Society
}

\author{
Sedat Bostan ${ }^{1}$, Ramazan Erdem ${ }^{2}$, Yunus Emre Öztürk ${ }^{3}$, Taşkın Kılıç ${ }^{1^{*}}$, Ali Yılmaz ${ }^{4}$
}

\author{
${ }^{1}$ Ordu University, Faculty of Health Sciences, Department of Health Management, Ordu, TURKEY \\ ${ }^{2}$ Süleyman Demirel University, Faculty of Economics and Administrative Sciences, Department of Health Management, Isparta, TURKEY \\ ${ }^{3}$ Selçuk University, Faculty of Health Sciences, Department of Health Management, Konya, TURKEY \\ ${ }^{4}$ Kırıkkale University, Faculty of Health Sciences, Department of Health Management, Kırıkkale, TURKEY \\ *Corresponding Author: taskinkilic79@hotmail.com
}

Citation: Bostan S, Erdem R, Öztürk YE, Kılıç T, Yılmaz A. The Effect of COVID-19 Pandemic on the Turkish Society. Electron J Gen Med. 2020;17(6):em237. https://doi.org/10.29333/ejgm/7944

\section{ARTICLE INFO}

Received: 1 Apr. 2020

Accepted: 11 Apr. 2020

\begin{abstract}
Pandemics leave significant marks on the memories of societies with their permanent impacts. Going beyond a cause of disease or death, they can have consequences in many aspects, psychological, social and economic ones being in the first place. The Covid-19 outbreak, which first emerged in China and has spread to the whole world as of the first months of 2020, has the potential to constitute a breaking the course of history, as well. Turkey is located on the transit point between Asia and Europe with its geographical position, and thus, received its share from the outbreak of Covid-19, which spreads through social contact. The first official case was recorded on 11 March 2020, and then the virus spread rapidly. This study aims to assess the attitude of the public towards Covid19 at times when the impact of the disease reached maximum. To this end, data were collected from 1586 people with different socio-demographic features through Covid-19 Pandemic Community Scale. The impact of the pandemic on the society was measured in three dimensions as Sensitivity to Pandemic, Protection against Pandemic and Social Trust. The research results showed that the people had high levels of sensitivity to the pandemic, exerted the maximum effort for protection and social trust was above the average although it fell behind the other dimensions. As a consequence, it can be concluded that Covid-19 has had a significant impact on the Turkish people.
\end{abstract}

Keywords: covid-19, pandemic, covid-19 pandemic community scale

\section{INTRODUCTION}

Meanings ascribed to disease and health and their implications on the social arena continue attracting the attention of researchers. During their lifetimes, all living creatures go between health and diseases. Although diseases are personal, the disease starts to influence first the relatives of the patient and then the whole social circle. Issues such as suffering of many people from diseases, clustering of diseases by social layers, social and cultural phenomena of the diseases and inequalities experienced in access to health services lay the ground for the examination of the problem with a sociological perspective. As for pandemics, as they threaten many people with the same disease, they affect societies in a different manner from classical diseases. Pandemics have a particular place in the memories of the societies. They cause large masses to live in a state of fear and anxiety and disrupt the natural flow of the life, and everybody has a particular experience regarding the pandemic. Thus, a medical history to be transferred from one generation to another emerges. The emerging outbreaks can have different impacts on the segments of the society. While these impacts can change by the type of the disease, they can also change from one society to the other depending on the cultural features.
Many major pandemics have occurred throughout history, and the crises associated with pandemics have made great adverse impacts on health, economy and even national security on the world (1). It is known that the germs causing pandemics are as old as the humanity itself, and the history of pandemics goes back a long way. In the $14^{\text {th }}$ century B.C., plague, small pox, leprosy, malaria and cholera affected many parts of the world. Some of these diseases resulted in serious economic and political damages to the societies by causing high numbers of deaths (2). The plague pandemic, which spread between the years $1346-1350$ and has come to be known as the "black death", is one of the pandemics cited as example in history. The pandemic had severe demographic consequences by resulting in the death of 35 million people in China and 25 million people in Europe. It affected some regions and practitioners of some professions much more than the others. The city of Florence lost $75 \%$ of its population, and the clergies and physicians, who had higher likelihood for contacting the patients, had higher chances for getting the disease, as well (3). The spread of epidemics or their consequences may vary from one society to the other. Human biology, social environment and lifestyles are the variables affecting the rate and level of spread and consequences of pandemics (4). It has been reported that awareness regarding the epidemic diseases and taking personal and societal measures to counter the spread of the pandemic are important and effective in minimising the negative impacts of the disease 
(5). On the other hand, most importantly, pandemics contributed to the development of sciences dealing with the living creatures, and the medical science, in particular. However, they also shook the prestige of institutions such as the church, which had an important place in the society, and thus, made significant social impacts (6).

More recently, different viruses, SARS in 2003, influenza (H1N1) in 2009, MERS in 2012, Ebola in 2014, Zika virus in 2016 and COVID-19 in 2019, affected many people on the world and resulted in high death tolls $(7,8)$. As the disease spreads to a high number of people; disruption of communal life conditions, closure of schools and loss of social peace due to the measures taken with the aim of eliminating the impacts of the virus inevitably affect social life (9). The pandemics reaching a life-threatening level increase anxiety levels and avoidance behaviours of people, and bring social life to a standstill (10). The labour losses resulting from the effects of epidemic diseases are among the socio-economic losses caused by the diseases. Pandemics damage national economies due to the budget allocated to the prevention and treatment of the disease on a broad sense and socio-economic conditions and individuals and families on a narrow sense (11).

It is useful to address the social impacts of epidemic diseases on macro and micro levels. On a macro level, the relation between globalisation and health is important. According to one of the models explaining the relation of globalisation with health, infectious diseases directly affect health (12). The COVID-19 virus, which was first identified in China in December 2019, primarily reveals the impact of globalisation on health. The spread of the virus almost to the entire world just within about two months has required all countries to deal with the same problem (13). In the globalising world, pandemics and their likelihood to occur frighten people. First Ebola, SARS, avian flu and swine flu and now COVID-19 have emerged. COVID-19 infection can cause serious diseases, which might result in death, and also gives socio-economic damages (14). Many countries allocate significant amounts of budgets with the aim of protecting their citizens against these diseases. Economic crises can happen in the countries where the pandemic emerged or spread to (15). While globalisation is a negative element in the spread of the diseases, it has a positive effect in terms of the discovery and exchange of the treatment method (16). The exchange of global data sets, combination of different areas of specialities from different countries and cooperation on the new technologies that may prevent diseases are only possible through globalisation (17).

One of the aspects of globalisation affecting health is media tools. A disease identified in any part of the world, measures taken with respect to that disease or the situation of the disease can be transmitted to all corners of the worlds through audio, written or visual channels. It is beyond doubt that media has a positive impact when it is assessed in terms of measures and information. However, presenting what actually happens in an exaggerated or provocative manner creates a climate of fear in the society. This affects the psychological health of the people, who does not even surfer from the endemic disease, in a negative manner $(17,18,19)$. Different explanations by different experts on the disease cause confusions about what is wrong and what is correct, and all kinds of manipulative information can be circulated rapidly through social media. An agenda full of pandemic, number of cases and death toll has serious impacts on the community psychology.
On the micro level, social distancing stands out. Social distancing consists of measures such as keeping physical distance among individuals in the society with the aim of preventing the spread of contagious diseases such as COVID-19 (10). There are studies showing that these measures managed to prevent the spread of the virus in China (20). Although social distancing affects every individual within the society, it can be claimed that the group affected at most by this situation is the elderly. Since the elders have chronic diseases and have weak immune systems, they are at higher risk of suffering from the negative effects of COVID-19 (21,22). Therefore, significant measures are taken for protecting the elders against this virus. The elderly can be protected against virus through social distancing, which is one of the most important measures, but different problems can accompany. Courtin and Knapp reported that social isolation and loneliness had negative impacts on physical and mental health in old age (23). Pandemics, which require the isolation of the patients or suspected patients from the rest of the society, have caused the isolation of regions where disease is detected (6).

Another important social issue is "stigmatisation". Stigmatisation is the action of disgracing an individual in the eyes of the society by declaring that individual defective due to any handicap, race, dependence or any disease considered to be risky by the society (24). With the spread of COVID-19 pandemic to the whole world, many people/groups including the elders, travellers, foreigners, healthcare professionals, patients and their relatives have become targets. The individuals refraining from stigmatisation might hide their diseases and thus, can facilitate transmission. Also, the concern of stigmatisation can forestall the disease and negatively affect treatment (21). The news about the allegation that a person of Afghan origin, who was fishing, was stabbed by a person who said 'You are bringing corona virus here' (25) proves that foreigners have been stigmatised about the spread of COVID-19 virus. It is certain that the stigmatised individuals have difficulties in the social processes. According to the results of the study conducted by Bird et al, the patients with HIV face challenges in the use of healthcare services (26).

Various epidemic diseases, which have spread in recent years, result in a fear of disease in the society and also require countries to ensure their own safety in the field of health. In today's world where wars are not waged only through guns, the field of health is considered to be risky, as well. Despite the expansion of individual freedoms in the $20^{\text {th }}$ century, an environment of insecurity is in question. This situation causes societies to constantly feel themselves under risk (27). Epidemic diseases have negative social impacts on the patients and their relatives as well as high treatment costs and labour losses. Providing protective healthcare services aiming at preventing pandemics and taking the necessary measures before the outbreak of the diseases are more advantageous approaches in the long term (28).

The features of a pandemic can be listed as follows: spread over a wide geographical area, disease movement, novelty, severity, high spread rates and reproduction, minimal population immunity and infectiousness and contagiousness (1). The COVID-19 outbreak possesses all these features. As a new type of virus, it has spread to almost all countries and has fatal effect on the elderly patients and those having another chronic disease.

In Turkey, the first official case diagnosed with COVID-19 was announced on 11 March 2020, and the first death was 
recorded on 17 March 2020. Following the first case, numbers have rapidly increased, and the number of cases exceeded 10.000 while the death toll exceeded 150 in 20 days (29). For the management of the process, Ministry of Health established a scientific board and developed strategies to fight against COVID-19 in line with the recommendations of the board. With the aim of containing the virus, trips abroad were taken under control, domestic trips were restricted, a curfew was imposed on the citizens over the age of 65 , formal education in the schools was halted and distance education system was introduced. The package called as "Economic Stability Shield" in order to minimize the effects of the pandemic on the economy. The experiences of countries such as China where the virus emerged and Iran and Italy, which met the virus earlier, cause concerns and anxiety among the Turkish society.

Rolland identified three phases in the development of a disease: crisis, chronic and terminal. The crisis phase covers the first period of adaptation and acceptance, the chronic phase is the period when the patient and the family try to cope with certain psychological and social permanent changes caused by the disease, and the terminal phase covers the period when the death becomes apparent and dominates family life, the death, the period when the family grieves and mourns over the death and the return to normal family life following the loss (30). If we adapt this model to a society fighting with a pandemic, the crisis phase is the period when the first cases are reported and the society faces the disease, the chronic phase is the period when the society starts to fight with the disease and transforms itself according to it, and the terminal phase is the period when the pandemic is eradicated and the resulting damage is compensated. We can state that Turkey is now going through the chronic phase.

Today the phenomenon of health/disease is not only a personal, biological issue but has turned into a political, economic, societal and technological issue (31). This study aimed at examining the social implications of COVID-19 by addressing the case of Turkey. The study also aimed to reveal the attitude of the society towards COVID-19 and how it was affected by the pandemic at a time when its impact reached the maximum. Since an assessment on the approach of the general public towards the pandemic in a period when it reaches the peak will be a reference for future studies, this research is deemed important.

\section{MATERIAL AND METHODS}

\section{Research Population and Sample}

The population of the research consists of Turkey and the people living in Turkey. Due to the COVID-19 pandemic, which is the subject of the study and is still ongoing in Turkey and around the world, social isolation and social distancing are being implemented as legal requirements.

Under these conditions, data collection can be carried out via internet only by using digital tools. Therefore, the data of the study were obtained through a survey created on Google search engine. For the participation in the survey, announcements were made on social media. Since it was not possible for the researchers to determine the participants in the digital environment, convenience sampling was used in data collection.
In addition, convenience sampling was selected since this method makes data collection process easier, more cost effective and faster when compared to the other sampling techniques. ${ }^{1}$

The data collection process started on 3.29.2020 at 0:29:14 and ended on 3.29.2020 at 23:20:50. The total duration is about one day. In this period of time, 1586 valid surveys were submitted. This figure is considered to be adequate for the population of the research.

\section{Data Collection Tools}

Data of the research were collected in two parts: question form for demographic information and "COVID-19 Pandemic Community Scale."

Demographic Information: Demographic attributes of the participants consist of two open-end questions examining the status of facing with COVID-19 pandemic and the success of the countries in the fight against the pandemic. In this part, information of the participants with respect to profession, education level, gender, age, income, place of residence, contacting COVID-19, taking test, being infected and receiving treatment.

COVID-19 Pandemic Community Scale: The scale was drafted in accordance with the information about the pandemic, literature review, preliminary interviews held with the individuals in the society as well as the opinions of physicians, healthcare professionals and scholars specialised in the field. It was reviewed by seven scholars specialised in the field, some questions were left out, statements were revised, and as a result, it was restructured with 34 statements in total.

SPSS program was used in the validity and reliability tests of COVID-19 Pandemic Community Scale. Factor analysis was conducted to assess the construct validity of the items of the scale. Kaiser-Meyer-Olkin (KMO) test was carried out for the sample number, and it was determined as 0,882. Also, the results of Bartlett Globality Test were used to determine whether the inter-item correlation was significant, and it was determined that it was significant at the 0.001 level (Approx. Chi-Square: 16748,112/ df: 378/ sig: 0.000). Principal components method with "Direct Oblimin" rotation procedure was applied to size the items. Scale items with factor loads of 0.40 and above are defined as high loading. ${ }^{2}$ In the scale consisting of 34 items, six items were left out due to inadequate factor loadings, and the final scale included 28 items. Accordingly, all items had factor loadings above 0.40 . It can be stated that the scale items have high factor loadings. COVID-19 Pandemic Community Scale had three factors. These were named as Sensitivity to Pandemic (12 items), Protection against Pandemic ( 7 items) and Social Trust during Pandemic (9 items). The level of the factors constituting the scale to explain the variance was calculated as 44.257 in total (Sensitivity to Pandemic - 15,490; Protection against Pandemic - 10,883; Social Trust during Pandemic -17,885). Cronbach's Alpha coefficient was checked for the reliability analysis of the scale and was found as 0.796 . Thus, it can be argued that the scale had a Cronbach a coefficient higher than 0,60 , and thus, had high reliability. Besides that this study Complies with The World Association of Physicians (DTB) Helsinki Declaration (2013) ethical rules. Data were analysed in the SPSS package program through frequency and significance tests. 
Table 1. Frequency Distribution of Demographic Variables (April 4th, 2020)

\begin{tabular}{|c|c|c|c|c|c|}
\hline Variable & $\mathbf{N}$ & $\%$ & Variable & $\mathbf{N}$ & $\%$ \\
\hline 1.Profession & & & 6. Place of residence & & \\
\hline Public official & 395 & 6.8 & Province/Centre & 1020 & 64.3 \\
\hline Worker & 108 & 6.8 & District/Centre & 363 & 22.9 \\
\hline Housewife & 63 & 4.0 & Village & 67 & 4.2 \\
\hline Retired & 57 & 3.6 & 6. Marital status & & \\
\hline Unemployed & 27 & 1.7 & Married & 785 & 49.5 \\
\hline Student & 545 & 34.4 & Single & 762 & 48.0 \\
\hline Healthcare professional & 156 & 9.8 & Widow & 39 & 2.5 \\
\hline Self-employed & 235 & 14.8 & 7. Whom do you live with? & & \\
\hline 2.Education Level & & & Family & 1361 & 85.8 \\
\hline Primary or secondary school & 31 & 2.0 & Alone & 114 & 7.2 \\
\hline High school or vocational high school & 138 & 8.7 & Friends & 53 & 3.3 \\
\hline Associate degree & 194 & 12.2 & Dormitory & 58 & 3.7 \\
\hline Bachelor's degree & 859 & 54.2 & & & \\
\hline Graduate degree & 364 & 23.0 & 8. Have you ever come across a Covid-19 positive patient? & & \\
\hline 3.Gender & & & Yes & 60 & 3.8 \\
\hline Female & 803 & 50.6 & No & 1526 & 96.2 \\
\hline Male & 783 & 49.4 & 9. Has any one of your relatives been diagnosed with Covid-19? & & \\
\hline 4.Age & & & Yes & 48 & 3.0 \\
\hline$\geq 29$ & 742 & 46.8 & No & 1538 & 97.0 \\
\hline 30-39 age range & 346 & 21.8 & 10. Have you been tested for Covid-19? & & \\
\hline 40-49 age range & 294 & 18.5 & Yes & 8 & 0.5 \\
\hline 50-59 age range & 161 & 10.2 & No & 1578 & 99.5 \\
\hline \multirow[t]{2}{*}{$60 \leq$} & 36 & 2.3 & 11. If you have, what is the result? & & \\
\hline & & & Positive & 4 & 50.0 \\
\hline 5. Average monthly income & & & Negative & 4 & 50.0 \\
\hline $0-2500 \mathrm{TL}$ & 478 & 30.1 & 12. If you have been infected by the virus, what is your current situation? & & \\
\hline 2.501-5.000 TL & 493 & 31.1 & No symptoms, under quarantine & 1 & 25.0 \\
\hline $5.001-10.000 \mathrm{TL}$ & 425 & 26.8 & Inpatient treatment & 2 & 50.0 \\
\hline $10.000+\mathrm{TL}$ & 77 & 7.1 & Recovered & 1 & 25.0 \\
\hline
\end{tabular}

\section{RESULTS}

Results related to the demographic information of the participants and the variables concerning COVID-19 are given in Table 1.

When the data in the Table 1 are examined, it is seen that students stand out with $34.4 \%$ in the distribution of the participants by profession and they are followed by public officials, self-employed and healthcare professionals. It is thought that the collection of data via internet increased the participation of students. Although the holders of bachelor's and graduate degrees have higher shares in the distribution of education levels, it is understood that the graduates of associate degree programs, high schools, primary and secondary schools are represented at a significant level. Since data were collected in the internet environment, high participation rates of those with higher education levels are an expected situation. The distribution of female and male participants is almost equal.

Although the age distribution shows that young participants are dominant among the participants with $46.8 \%$ of them being under the age of 29 , it is clear that there are participants from all age groups. In terms of income level, the first three groups are close to one another. $64.3 \%$ of the participants live in provinces, $22.9 \%$ of them live in district centres and $4.2 \%$ of them live in villages. This distribution resembles to the general distribution of the country. The rates of the married and single participants are too close. Finally, the rate of the participants living with their families is considerably high (85.8\%).
According to the results, only 60 participants came across a COVID-19-positive patient, eight participants were tested for COVID-19 and four of them were found positive. Out of these four patients, one patient did not show symptoms, two patients received inpatient treatment and one patient recovered.

Frequency distribution of the items included in the components of the COVID-19 Pandemic Community Scale titled Sensitivity to Pandemic, Protection against Pandemic and Social Trust during Pandemic is given in Table 2.

According to these findings, the society in general acts more sensitively in terms of protection against pandemic (4.40). However, it can be stated that the averages of Sensitivity and Social Trust factors are good. The society displayed the highest reaction in relation to disagreement with the view that it does not cause harm to us (4.56). The highest rates were obtained in the following protective measures, respectively: hygiene (4.7), social distancing (4.57) and staying at home (4.50). Also, the participants stated that the people that they are living with comply with the rules, as well (4.41). In terms of social trust factor, there is high level of trust in the health system and hospitals (4.07), in the authorities (3.84) and in the accuracy of the decisions taken by the state (3.73) in the fight against COVID-19. However, there are concerns about the appropriateness of the economic measures (2.87). There is moderate level of hope concerning the eradication of the pandemic in the summer months. The fight of Turkey against COVID-19 is not found successful when compared to the Western countries. Also, the rate of the participants agreeing with the statement that "COVID-19 has showed that the countries deemed to be powerful are not that powerful" is high (4.18). 
Table 2. Frequency Distribution of Covid-19 Pandemic Community Scale (April 4th, 2020)

\begin{tabular}{|c|c|c|c|c|c|c|c|c|c|c|c|c|}
\hline \multirow{3}{*}{ Items } & \multicolumn{10}{|c|}{ Examination of the Social Impact of the Covid-19 Pandemic } & \multirow{3}{*}{$\overline{\mathbf{x}}$} & \multirow{3}{*}{ SS } \\
\hline & \multicolumn{2}{|c|}{$\begin{array}{l}\text { Totally } \\
\text { disagree }\end{array}$} & \multicolumn{2}{|c|}{ Disagree } & \multicolumn{2}{|c|}{ Partially agree } & \multicolumn{2}{|c|}{ Agree } & \multicolumn{2}{|c|}{ Totally agree } & & \\
\hline & $\mathbf{n}$ & $\%$ & $\mathbf{n}$ & $\%$ & $\mathbf{n}$ & $\%$ & $\mathbf{n}$ & $\%$ & $\mathbf{n}$ & $\%$ & & \\
\hline & \multicolumn{6}{|c|}{ Sensitivity to Covid-19 Pandemic } & & & & & 3.78 & 0.055 \\
\hline 1. Covid-19 makes me really anxious. & 49 & 3.1 & 83 & 5.2 & 339 & 21.4 & 407 & 25.7 & 708 & 44.6 & 4.035 & 1.070 \\
\hline $\begin{array}{l}\text { 2. After Covid-19, I started remembering death } \\
\text { more often. }\end{array}$ & 163 & 10.3 & 164 & 10.3 & 352 & 22.2 & 348 & 21.9 & 559 & 35.2 & 3.615 & 1.328 \\
\hline 3. Covid-19 has made me mentally depressed. & 263 & 16.6 & 288 & 18.2 & 417 & 26.3 & 244 & 15.4 & 374 & 23.6 & 3.112 & 1.389 \\
\hline $\begin{array}{l}\text { 4. I have adjusted my whole life according to } \\
\text { Covid-19 pandemic. }\end{array}$ & 160 & 10.1 & 209 & 13.2 & 363 & 22.9 & 366 & 23.1 & 488 & 30.8 & 3.512 & 1.317 \\
\hline $\begin{array}{l}\text { 5. I feel concerned about transmitting Covid- } \\
19 \text { to the people I live with. }\end{array}$ & 98 & 6.2 & 106 & 6.7 & 206 & 13.0 & 323 & 20.4 & 852 & 53.8 & 4.088 & 1.128 \\
\hline $\begin{array}{c}\text { 6. I am concerned about transmitting Covid- } \\
19 \text { to a relative/friend and causing someone's } \\
\text { death. }\end{array}$ & 84 & 5.3 & 99 & 6.2 & 193 & 12.2 & 284 & 17.9 & 926 & 58.4 & 4.178 & 1.183 \\
\hline $\begin{array}{l}\text { 7. I do not approve the view that 'Covid-19 is } \\
\text { not something to fear and is being } \\
\text { exaggerated unnecessarily'. }\end{array}$ & 40 & 2.5 & 99 & 6.2 & 203 & 12.8 & 339 & 21.4 & 905 & 57.1 & 4.15 & 1.057 \\
\hline $\begin{array}{l}\text { 8. I do not adopt the attitude that 'I have not } \\
\text { been affected by Covid-19 at all'. }\end{array}$ & 61 & 3.8 & 87 & 5.5 & 261 & 16.5 & 310 & 19.5 & 867 & 54 & 4.18 & 1.119 \\
\hline $\begin{array}{l}\text { 9. I disagree with the view that Covid-19 does } \\
\text { not cause harm to us. }\end{array}$ & 26 & 1.6 & 37 & 2.3 & 128 & 8.1 & 232 & 14.6 & 1163 & 73 & 4.56 & 0.863 \\
\hline $\begin{array}{l}\text { 32. Covid-19 has increased my sensitivity } \\
\text { concerning pandemics. }\end{array}$ & 11 & 0.7 & 37 & 2.3 & 164 & 10.3 & 512 & 32.3 & 862 & 54.4 & 4.372 & 0.814 \\
\hline $\begin{array}{l}\text { 33. Covid-19 has changed my consumption } \\
\text { understanding in terms of economy. }\end{array}$ & 75 & 4.7 & 128 & 8.1 & 356 & 22.4 & 503 & 31.7 & 524 & 33.0 & 3.802 & 1.124 \\
\hline $\begin{array}{l}\text { 4. During the Covid-19 pandemic, significant } \\
\text { changes are taking place in my personal }\end{array}$ & 55 & 3.5 & 94 & 5.9 & 287 & 18.1 & 495 & 31.2 & 655 & 41.3 & 4.009 & 1.069 \\
\hline
\end{tabular}

behaviours in favour of human sensitivity.

\begin{tabular}{|c|c|c|c|c|c|c|c|c|c|c|c|c|}
\hline \multicolumn{11}{|c|}{ Protection against Covid-19 Pandemic } & \multirow{2}{*}{$\begin{array}{l}4.40 \\
4.647\end{array}$} & \multirow{2}{*}{$\begin{array}{l}\mathbf{0 . 0 5 0} \\
0.708\end{array}$} \\
\hline $\begin{array}{l}\text { 10. I take notice of the warnings of the } \\
\text { authorities on Covid-19. }\end{array}$ & 19 & 1.2 & 12 & 0.8 & 67 & 4.2 & 313 & 19.7 & 1175 & 74.1 & & \\
\hline 11. I have enough knowledge about Covid-19. & 19 & 1.2 & 29 & 1.8 & 251 & 15.8 & 670 & 42.2 & 617 & 38.9 & 4.158 & 0.838 \\
\hline $\begin{array}{l}\text { 12. I have adequate personal protective } \\
\text { materials. }\end{array}$ & 85 & 5.4 & 137 & 8.6 & 381 & 24.0 & 549 & 34.6 & 434 & 27.4 & 3.699 & 1.119 \\
\hline $\begin{array}{l}\text { 13. I comply with the general and hand } \\
\text { hygiene rules for protection against Covid- } 19 \text {. }\end{array}$ & 4 & 0.3 & 2 & 0.1 & 34 & 2.1 & 281 & 17.7 & 1265 & 79.8 & 4.766 & 0.509 \\
\hline $\begin{array}{l}\text { 14. I practise social distancing as a protection } \\
\text { against Covid-19. }\end{array}$ & 8 & 0.5 & 12 & 0.8 & 99 & 6.2 & 408 & 25.7 & 1059 & 66.8 & 4.570 & 0.689 \\
\hline $\begin{array}{l}\text { 15. I stay at home as a protection against } \\
\text { Covid- } 19 .\end{array}$ & 41 & 2.6 & 43 & 2.7 & 101 & 6.4 & 289 & 18.2 & 1112 & 70.1 & 4.505 & 0.922 \\
\hline $\begin{array}{l}\text { 16. People that I live with comply with } \\
\text { personal measures and hygiene rules. }\end{array}$ & 9 & 0.6 & 16 & 1.0 & 144 & 9.1 & 434 & 27.4 & 983 & 62.0 & 4.491 & 0.748 \\
\hline \multicolumn{11}{|c|}{ Social Trust in the Fight against Covid-19 Pandemic } & 3.48 & 0.82 \\
\hline $\begin{array}{l}\text { 18. I trust in the authorities in the fight against } \\
\text { Covid-19. }\end{array}$ & 102 & 6.4 & 105 & 6.6 & 331 & 20.9 & 445 & 28.1 & 603 & 38.0 & 3.846 & 1.187 \\
\hline $\begin{array}{l}\text { 19. I trust in the information provided by } \\
\text { media in the fight against Covid- } 19 \text {. }\end{array}$ & 162 & 10.2 & 206 & 13.0 & 521 & 32.8 & 436 & 27.5 & 261 & 16.5 & 3.269 & 1.183 \\
\hline $\begin{array}{l}\text { 22. I trust in our health system and hospitals } \\
\text { in the fight against Covid- } 19 \text {. }\end{array}$ & 59 & 3.7 & 63 & 4.0 & 288 & 18.2 & 473 & 29.8 & 703 & 44.3 & 4.070 & 1.055 \\
\hline $\begin{array}{l}\text { 23. I trust in the accuracy of the measures } \\
\text { taken by the government in the fight against } \\
\text { Covid- } 19 .\end{array}$ & 117 & 7.4 & 141 & 8.9 & 330 & 20.8 & 460 & 29.0 & 538 & 33.9 & 3.732 & 1.223 \\
\hline $\begin{array}{l}\text { 24. I trust in the correct implementation of the } \\
\text { measures in the fight against Covid-19. }\end{array}$ & 123 & 7.8 & 153 & 9.6 & 431 & 27.2 & 471 & 29.7 & 408 & 25.7 & 3.559 & 1.191 \\
\hline $\begin{array}{l}\text { 25.I trust in the appropriateness of the } \\
\text { economic measures taken with respect to } \\
\text { Covid-19. }\end{array}$ & 372 & 23.5 & 260 & 16.4 & 393 & 24.8 & 314 & 19.8 & 247 & 15.6 & 2.876 & 1.381 \\
\hline $\begin{array}{l}\text { 26. I think that we are more successful than } \\
\text { the Western countries in the fight against } \\
\text { Covid-19. }\end{array}$ & 193 & 12.2 & 171 & 10.8 & 385 & 204.3 & 372 & 23.5 & 465 & 29.3 & 3.469 & 1.335 \\
\hline $\begin{array}{l}\text { 27. I think that Covid-19 pandemic will lose its } \\
\text { effect with summer. }\end{array}$ & 178 & 11.2 & 204 & 12.9 & 523 & 33.0 & 400 & 25.2 & 281 & 17.7 & 3.253 & 1.214 \\
\hline $\begin{array}{l}\text { 28. Covid-19 has showed that the countries } \\
\text { deemed to be powerful are not that powerful. }\end{array}$ & 44 & 2.8 & 70 & 4.4 & 262 & 16.5 & 379 & 23.9 & 831 & 52.4 & 4.187 & 1.039 \\
\hline
\end{tabular}


Table 3. Professions of Participants (April 4th, 2020)

\begin{tabular}{|c|c|c|c|c|c|c|}
\hline & & $\mathbf{N}$ & Mean & $\begin{array}{c}\text { Std. } \\
\text { Deviation }\end{array}$ & $\mathbf{F}$ & $\mathbf{P}$ \\
\hline \multirow{8}{*}{ Sensitivity } & Worker & 108 & 3.7122 & .63141 & \multirow{8}{*}{3.950} & \multirow{8}{*}{.000} \\
\hline & Public official & 395 & 3.7527 & .56536 & & \\
\hline & Housewife & 63 & 3.8690 & .54844 & & \\
\hline & Retired & 57 & 3.5175 & .57729 & & \\
\hline & Unemployed & 27 & 3.8765 & .58167 & & \\
\hline & Student & 545 & 3.8327 & .54190 & & \\
\hline & $\begin{array}{l}\text { Healthcare } \\
\text { professional }\end{array}$ & 156 & 3.8307 & .56245 & & \\
\hline & Other & 235 & 3.7110 & .51082 & & \\
\hline \multirow{8}{*}{ Protection } & Worker & 108 & 4.3955 & .45243 & \multirow{8}{*}{2.088} & \multirow{8}{*}{.042} \\
\hline & Public official & 395 & 4.3888 & .50888 & & \\
\hline & Housewife & 63 & 4.5170 & .47479 & & \\
\hline & Retired & 57 & 4.3759 & .50984 & & \\
\hline & Unemployed & 27 & 4.4550 & .67010 & & \\
\hline & Student & 545 & 4.4511 & .47886 & & \\
\hline & $\begin{array}{l}\text { Healthcare } \\
\text { professional }\end{array}$ & 156 & 4.3178 & .48860 & & \\
\hline & Other & 235 & 4.3678 & .55591 & & \\
\hline \multirow{8}{*}{$\begin{array}{l}\text { Social } \\
\text { trust }\end{array}$} & Worker & 108 & 3.3870 & .99156 & \multirow{8}{*}{16.104} & \multirow{8}{*}{.000} \\
\hline & Public official & 395 & 3.5754 & .75116 & & \\
\hline & Housewife & 63 & 3.6333 & .80942 & & \\
\hline & Retired & 57 & 3.1772 & .96084 & & \\
\hline & Unemployed & 27 & 3.0111 & .78266 & & \\
\hline & Student & 545 & 3.6822 & .75566 & & \\
\hline & $\begin{array}{l}\text { Healthcare } \\
\text { professional }\end{array}$ & 156 & 3.2327 & .77060 & & \\
\hline & Other & 235 & 3.1774 & .79542 & & \\
\hline
\end{tabular}

According to the data given in Table 3 , the retired think in a different way from healthcare professionals, housewives and students, and they are less sensitive to COVID-19 pandemic. It is observed that housewives are more rigorous about protection measures. Also, social trust levels of students, housewives and public officials are higher than the other groups.

It was observed that the education levels caused difference in terms of social trust factor (F:3227 P: 0.012). Findings show that social trust levels of primary and secondary school graduates are higher when compared to those of the holders of postgraduate degrees.

It was determined that female participants were more careful about COVID-19 pandemic when compared to male participants in all of three factors.

It was concluded that the group having an income level of 0-2500 TL had higher levels of sensitivity and social trust when compared to the group with an average income of 5001-10000.

It is seen that those in the age group of 50-59 have lower sensitivity levels and are less likely to take protective measures when compared to the other groups. Also, in terms of social trust, those aged 29 and below have higher social trust levels when compared to the age groups of 30-39 and 40-49.

With two open-ended questions in the study, participants were asked to write the three most successful and unsuccessful countries in the fight against the pandemic. Accordingly, participants listed the top three most successful countries in the fight against COVID-19 pandemic as China (731 times), Turkey (611 times), South Korea (593 times), respectively. Germany (493 times) was mentioned as successful in the fight against the pandemic, as well. Among the top three most unsuccessful countries in the fight against COVID-19 pandemic, Italy (1299 times), Spain (692 times) and the USA (514 times)
Table 4. Age Variable of Participants (April 4th, 2020)

\begin{tabular}{|c|c|c|c|c|c|c|}
\hline & & $\mathbf{N}$ & Mean & $\begin{array}{c}\text { Std. } \\
\text { Deviation }\end{array}$ & $\mathbf{F}$ & $\mathbf{P}$ \\
\hline \multirow{5}{*}{ Sensitivity } & $\geq 29$ & 742 & 3.8214 & .54429 & \multirow{5}{*}{9.690} & \multirow{5}{*}{.000} \\
\hline & $30-39$ & 346 & 3.8276 & .53313 & & \\
\hline & 40-49 & 294 & 3.7443 & .55188 & & \\
\hline & 50-59 & 161 & 3.5595 & .59980 & & \\
\hline & $60 \leq$ & 36 & 3.5718 & .64308 & & \\
\hline \multirow{5}{*}{ Protection } & $\geq 29$ & 742 & 4.4257 & .49422 & \multirow{5}{*}{3.613} & \multirow{5}{*}{.006} \\
\hline & $30-39$ & 346 & 4.4096 & .51970 & & \\
\hline & $40-49$ & 294 & 4.3897 & .47331 & & \\
\hline & 50-59 & 161 & 4.2964 & .57578 & & \\
\hline & $60 \leq$ & 36 & 4.5992 & .36272 & & \\
\hline \multirow{5}{*}{$\begin{array}{c}\text { Social } \\
\text { trust }\end{array}$} & $\geq 29$ & 742 & 3.5891 & .77362 & \multirow{5}{*}{6.355} & \multirow{5}{*}{.000} \\
\hline & $30-39$ & 346 & 3.3382 & .83332 & & \\
\hline & $40-49$ & 294 & 3.4310 & .84342 & & \\
\hline & $50-59$ & 161 & 3.4373 & .86471 & & \\
\hline & $60 \leq$ & 36 & 3.4972 & .83409 & & \\
\hline
\end{tabular}

were listed respectively. Iran (351 times) and Britain (309 times) are among the countries considered to be unsuccessful in the fight against COVID-19 pandemic, as well.

\section{DISCUSSION}

As a conclusion, Turkey has just started its struggle against the COVID-19 pandemic, which broke out in China and spread to Turkey among other countries. Although it seems that the pandemic in Turkey is under control thanks to the measures and actions taken so far, the COVID-19 outbreak has the potential to get out of control and explode at any time. Under these circumstances, knowing the approach of the society towards the phenomenon and making plans and changing the practices accordingly are important.

According to the results of this study, although the Turkish society does not react to the epidemic with excessive sensitivity, indifference is not acceptable for the Turkish society, as well. Turkish people take compliance with the protective measures seriously. They pay attention to the warnings about washing hands and hygiene, social distancing and staying at home. Also, it has been observed by the participants that the society has a tendency to comply with the rules. There is trust in the authorities, health system and hospitals and accuracy of the decisions taken by the state in the fight against pandemic, and people attach importance to the information provided by the media channels as well as the correct implementation of decisions. Participants are cautious about the termination of the pandemic in the summer months and do not find Turkey much more successful than the other countries in the fight against pandemic. They state that all countries are weak against the pandemic. Finally, there are concerns about the economic measures taken.

General approaches of housewives, public officials, students, women and the young in relation to the fight against pandemic seem to be more positive. Results show that those with lower education and income levels have higher social trust levels. Also, participants find China, Turkey and South Korea successful in the fight against COVID-19 while Italy, Spain and the USA are among the unsuccessful ones.

The struggle against COVID-19 is a long and exhausting process. In this process, people need to have patience and fortitude, to maintain positive communication and to meet 
their basic needs without problem. This study was conducted just in the initial phase. It is highly crucial that the people, who stay at home and break out of the routine, maintain their patience and survive this tragic period in psychological and economic terms. As the time prolongs, societal attitudes may change. Thus, the authorities should continue their transparent and informative attitudes with the aim of preserving and even enhancing social trust, and the media should broadcast by taking the social psychology into consideration. Maybe most importantly, information should be provided or actions should be taken in order to enhance the social trust related to the economic measures.

The authorities should continue the struggle through sustainable strategies, policies and practices to attain success with the measures taken. It is essential to make the positive support provided by the society to the fight against pandemic sustainable.

Similar scholarly works should be conducted at certain intervals with the aim of tracking changes and should be published without delay to help the authorities review their plans and practices.

\section{REFERENCES}

1. Qiu W, Rutherford S, Mao A, Chu C. The Pandemic and its Impacts. Health, Culture and Society, Dec. 2017:1-11. https://doi.org/10.5195/hcs.2017.221

2. Yolun M. İspanyol Gribinin Dünya ve Osmanlı Devleti Üzerindeki Etkileri, Adıyaman Üniversitesi Sosyal Bilimler Enstitüsü Tarih Anabilim Dalı, Yüksek Lisans Tezi, Adıyaman. 2012. Availablee at: http://dspace.adiyaman. edu.tr:8080/xmlui/bitstream/handle/20.500.12414/118/Mu rat\%20YOLUN.pdf? sequence=1\&isAllowed=y

3. Shaw M, Dorling D, Mitchell R. Health, Place and Society. Pearson Education Asia pte Ltd. London 2002.

4. Herring DA. Sattenspiel L. Social Contexts, Syndemics, and Infectious Disease in Northern Aboriginal Populations, American Journal of Human Biology 2007;19(2):190-202. https://doi.org/10.1002/ajhb.20618 PMID:17286253

5. Caley P, Philp DJ, McCracken K. Quantifying Social Distancing Arising from Pandemic Influenza, Journal of the Royal Society Interface, 2008;5(23):631-9. https://doi.org/ 10.1098/rsif.2007.1197 PMID:17916550 PMCID:PMC3226987

6. Özden K, Özmat M. Salgın ve Kent: 1347 Veba Salgınının Avrupa'da Sosyal, Politik ve Ekonomik Sonuçları, Idealkent, 2014, 5(12): 60-87. Available at: https://dergipark.org.tr/tr/download/article-file/461752

7. Er AG, Ünal S. 2019 Koronavirüs Salgını, Anlık Durum ve Illk İzlenimler, Flora, 2020;25:1-5. https://doi.org/10.5578/ flora.202001

8. Peeri NC, Shrestha N, Rahman MS, Zaki R, Tan Z, Bibi S, Baghbanzadeh M, Aghamohammadi N, Zhang W, Haque U. The SARS, MERS and Novel Coronavirus (COVID-19) Epidemics, The Newest and Biggest Global Health Threats: What Lessons Have We Learned?, International Journal of Epidemiology, 2020;1:1-10. https://doi.org/10.1093/ ije/dyaa033 PMid:32086938
9. Teo SSS, Nguyen-Van-Tam JS, Booy R. Influenza burden of illness, diagnosis, treatment, and prevention: what is the evidence in children and where are the gaps?Archives of Disease in Childhood 2005;90:532-536. https://doi.org/10.1136/adc.2004.051896 PMid:15851443 PMCid:PMC1720404

10. Çırakoğlu OC. Domuz Gribi (H1N1) Salgınıyla İlişkili Algıların, Kaygı ve Kaçınma Düzeyi Değişkenleri Bağlamında İncelenmesi, Türk Psikoloji Dergisi, 2011;26(67). Available at: www.psikolog.org.tr/tr/yayin lar/dergiler/1031828/tpd1300443320110000m000096pdf

11. Şanlı K. İnfluenza Virüsü ve Domuz Gribi, Jinekoloji Obstretrik Pediatri Dergisi (2010). 2(1): 4-12. Available at: http://www.logosyayincilik.com/menu/71/jinekolojiobstretrik-pediatri-dergisi-subat-2010

12. Labonté R, Schrecker T. Globalization and social determinants of health: Introduction and methodological background (part 1 of 3). Global Health. 2007;3:5. https://doi.org/10.1186/1744-8603-3-5 PMid:17578568 PMCid:PMC1924848

13. Ankaralı H. Ankaralı S. Erarslan N. COVID-19, SARS-CoV2, Enfeksiyonu: Güncel Epidemiyolojik Analiz ve Hastalık Seyrinin Modellemesi”, Anadolu Kliniği Tıp Bilimleri Dergisi, 2020;25(1):1-22. https://doi.org/10.21673/anadoluklin.707 038

14. Karcıoğlu Ö. What is Coronaviruses, and How Can We Protect Ourselves?", Phoenix Medical Journal, 2020, 2 (1): 66-71. Available at: https://dergipark.org.tr/en/download/ article-file/990396

15. Alu A. Küreselleşme ve Sağlık. Sağlık ve Sosyal Refah Araştırmaları Dergisi, 2019;1(1):1-9. Available at: https://dergipark.org.tr/tr/pub/sarad/issue/44045/541482

16. Hayran, O. Küreselleşme ve Sağlık İlişkileri, Sağlık Düşüncesi ve Tıp Kültürü Platformu, (2007). Available at: http://www.sdplatform.com/Dergi/6/Kuresellesme-vesaglik-iliskileri.aspx

17. Balta E. Kara Vebadan Koronavirüse Küreselleşme, Panorama, Uluslararası İlişkiler Konseyi, 2020, Retrieved from https://www.uikpanorama.com/blog/2020/02/10/ka ra-vebadan-koronaviruse-kuresellesme/

18. Bulduklu Y, Karaçor S. Sağlık Hizmetlerinde Kriz İletişimi Ve Yeni Medya. Atatürk Illetişim Dergisi. 2017; (14): 296-279. Available at: https://dergipark.org.tr/tr/pub/atauniiletisim /issue/34005/357162

19. Darı A. Sosyal Medya ve Sağlık. 21. Yüzyılda Eğitim Ve Toplum Eğitim Bilimleri Ve Sosyal Araştırmalar Dergisi, 2017;6(18):731-58. Available at: https://dergipark.org.tr/ $\mathrm{tr} /$ pub/egitimvetoplum/issue/36222/407951

20. Prem K, Liu Y, Russell TW, Kucharski AJ, Eggo RM, Davies N. The Effect of Control Strategies That Reduce Social Mixing on Outcomes of the COVID-19 Epidemic in Wuhan, China: A Modelling Study, The Lancet, 2020. https://doi.org/10.1016/S2468-2667(20)30073-6

21. Türkiye Psikiyatri Derneği, COVID-19 ve Damgalama, Türkiye Psikiyatri Derneği, Ruhsal Travma ve Afet Çalışma Birimi, (2020). Available at: https://www.psikiyatri.org.tr/ uploadFiles/243202019327-DamgalanmaCOVID.pdf

22. Bilim ve Aydınlanma Akademisi, Yeni Koronavirüs (2019Ncov) Salgını Ön Raporu, Toplum Sağlığını Koruma ve Geliştirme Bilim Alanı, 2020. Available at: http://bilimveaydinlanma.org/content/images/pdf/rapor/ yeni-koronavirus-2019-ncov-salgini.pdf 
23. Courtin E, Knapp M. Social Isolation, Loneliness and Health In Old Age: A Scoping Review, Health Soc Care Community. 2017 May;25(3):799-812. https://doi.org/10.1111/hsc.12311 PMid:26712585

24. Goffman E. Stigma: Notes on the Management of Spoiled Identity, 1963.Prentice-Hall Inc., Englewood Cliffs, New Jersey, USA.

25. Haberler.com,2020 Available at: https://www.haberler. com/afganli-sahis-buraya-korona-virusu-mu-13009387haberi/ (Accessed 30 March 2020).

26. Bird ST, Bogart LM, Delahanty DL. Health-Related Correlates of Perceived Discrimination in HIV Care, AIDS Patient care and STDs, 2004;18(1):19-26. https://doi.org/ 10.1089/108729104322740884 PMID:15006191

27. Fedai R, Uluslararası Örgütlerin Müdahale Alanı Olarak Sağlık: Yeni Bir Kavram Olarak Global Health Security, ASSAM Uluslararası Hakemli Dergi. 2019:15-23. Available at: https://dergipark.org.tr/tr/pub/assam/issue/48907/62361 3
28. Oysul FG, Bakır B. Orta Doğu Solunum Sendromu-MERS”, Türkiye Klinikleri, 2015;1(3):46-52. Available at: www.turkiyeklinikleri.com/article/tr-orta-dogu-solunumsendromu-mers-74196.html

29. T.C. Saglik Bakanligi. Turkiye'deki guncel durum. 2020. Available at: https://covid19.saglik.gov.tr/ (Accessed 31 March 2020)

30. Rolland JS. Chronic Illness and the Life Cycle: A Conceptual Framework, Family Process, 1987;26:203-21. https://doi. org/10.1111/j.1545-5300.1987.00203.x PMid:3595826

31. Aytaç Ö, Kurtdaş M. Sağlık - Hastalığın Toplumsal Kökenleri Ve Sağlık Sosyolojisi. Fırat Üniversitesi Sosyal Bilimler Dergisi. 2015;25(1). https://doi.org/10.18069/fusbed.31544 